Published as N. Monteix, "Perceptions of technical culture among Pompeian élites, considering the Cupids frieze of the Casa dei Vettii », in K. Droß-Krüpe, S. Föllinger and K. Ruffing (eds.), Antike Wirtschaft und ihre kulturelle Prägung (2000 v.Chr. - 500 n.Chr.) The cultural shaping of the Ancient economy, Wiesbaden, 2016 (Philippika, 98), p. 199-221.

Original page numbers are given into [brackets]. Fig. 7-8 were published in black and white.

\title{
Perceptions of Technical Culture among Pompeian Élites Considering the Cupids Frieze of the Casa dei Vettii
}

\author{
Nicolas Monteix
}

For much of the $20^{\text {th }}$ century, a historiographic trend, now in decline, adopted the general contempt displayed by some Latin writers against tradespeople. Following Cicero or Seneca, historians have long considered that the Roman elite perceived economic activity, particularly small scale, with disdain and distance. Yet new studies, based on literary, epigraphic and archaeological data, allow us to review afresh the involvement of the elite in the economy.

This paper aims to test whether it is possible to perceive economic practices through cultural markers. ${ }^{1}$ More specifically, I will seek to highlight technical culture amongst elites. By 'technical culture' I refer to the first degree of technical knowledge, possibly only very minimal, that enables a person to understand the environment in which he operates. ${ }^{2}$ Such an understanding of technical culture, at its most basic level, might allow the holder of a key to interact with it, through various actions,

$$
\text { tion. }
$$

1 Economic practices will be here limited to urban produc-

2 For a general and contemporary definition of 'technical culture', see de Noblet 1981.

3 The main issue concerns our ability to determine the extent of an individual's involvement in production, although this can be much elucidated by understanding their professional status; for example, highlighting differences between the practitioner and the contractor. See Tran 2013, 21-60.

4 F. De Angelis (2011) presented the most comprehensive synthesis on the proposed interpretations of the relationship between the decoration of the Casa dei Vettii and its supposed depending on increasing degrees, from its simple use in opening a closed door, to an understanding of the whole lock mechanism. A second aspect of technical culture to consider, partially relating to the first, concerns the relation between individuals and the technology of production. In attempting to determine if they were themselves involved or not in production, I will explore whether obtaining this technical culture could have been direct, through practice. $^{3}$

A particularly rich example to address these questions, at least historiographically, ${ }^{4}$ concerns the Casa dei Vettii in Pompeii (VI 15, 1.27). Excavated in 1895, it quickly became a focal point in the historiography of the city, mainly because of the outstanding quality of the paintings discovered inside..$^{5}$ Its name derives from the discovery of two bronze seal rings, the first bearing the name of A. Vettius Conviva and the second of A. Vettius Restitutus. ${ }^{6}$ Two painted inscriptions on the house's facade suggests a link between

owners. I here refer broadly to this article so to avoid increasing the length of notes and bibliography, differences of opinion notwithstanding.

5 On the excavation history and the first descriptions of this house, see NSc 1895, 31-34, 47, 84, 108-109, 207, 233-234, 251, 326, 352-353, 396; Mau 1896, 189; Sogliano 1898.

6 M. Della Corte $(1965,465-470)$ gives the most exhaustive list of such bronze seal rings discovered in Pompeii; see nr. 98 and 100. A third bronze seal ring, bearing P. Crusus Faustus' name was discovered in the upper part of the house (Della Corte 1965, nr. 34, p. 467). It remains difficult to assess whether the first floor it came from belonged or not to the Casa dei Vettii. 
these individuals and the building, although one of these inscriptions bears only one of the two names. ${ }^{7}$ Despite the gaps and uncertainties in our [199] documentation, it has been generally accepted that the AA. Vettii were the owners of the house and that its decor reflects their taste. This paradigm has been broadly accepted, following the work of M. I. Rostovtzeff who, after asserting, and with little scrutiny, the Vettii's status as freedmen, proposed that, like Trimalchio, they chose to represent the activities through which they had enriched themselves on the frescoes that adorned the walls of their main reception room. ${ }^{8}$ This simplistic view that considered that the Vettii, being freedmen represented their economic activities on the walls of their house, just as Trimalchio, was then much echoed by successive work.

To explore the concept of technical culture and to understand its implications and limitations, I will focus on the frieze of room q with its representations of Cupids in various scenes of production, notwithstanding the remarks by L. H. Petersen. ${ }^{9}$ However, to avoid some historiographic shortcomings, I will not take into consideration the supposed owners or their supposed civic status. Moreover, I will regard the names of the occupants, a term preferable to 'owners', of that house or their social status as not established and thus I will not consider them in the discussion. ${ }^{10} \mathrm{Be}-$ fore addressing methodological issues, it is worth mentioning several points about the paintings in room q. It cannot be overemphasized that the frieze belonged to a much wider iconographic pro-

7 CIL IV, 3509: Vetti Con[vi]va Augustali[s]; CIL IV, 3522: [[---]] Sabinum aed(ilem) | [[---]] Restitutus rog(at). The second inscription is severely damaged which leaves its reading and identification of the rogator, as A. V ettius Restitutus, uncertain. However, this identification remains widely accepted; see Weber et al. 2011, ad loc.

8 "I think that the Vettii who were the owners of this house were freedmen of the noble house of the Vettii" (Rostovtzeff 1957, 92). "[...] It is very probable (as already stated) that the Vettii, who owned this beautiful house, selected the special trades which are portrayed on the walls of its best room because they had a personal interest in them [...]. It is plain, too, that the rich Pompeians took pride in exhibiting to their friends pictures illustrating - in a slightly romantic manner (Cupids being substituted for men) - the modest occupations which contributed to their wealth and influence. The bourgeoisie of the cities was not ashamed of its prosaic callings: witness, for example, the candour with which the typical representative of the class, Trimalchio, tells the whole story of his life [...] in the pictures which adorned his house [...]" (Rostovtzeff 1957, 96). gram designed to provide a framework for dining. It is unfortunate that most of the main elements, such as the large rectangular wooden frames set in each of the walls, remain unknown, either because of their collapse ${ }^{11}$ or because they had not been inserted into the wall at the time of the eruption. ${ }^{12}$ The frieze itself is not without damage: only ten of the likely f ourteen original panels showing Cupids occupied by various activities are preserved while two of the panels are considerably degraded. Its location in the decorative scheme is such that the frieze remains in a globally secondary position. Despite this, when the room was used for banquets with the guests lying down on couches, the frieze remained visible, even in a position more suited to viewing than the higher central paintings. However, we cannot assume that the guests turned to stare at it during the banquet and then discussed its subjects with their neighbours as has been proposed by J. Clarke. ${ }^{13}$ Finally, it should also be noted that the Cupids and Psyches, considered [200] as divinities without cult, ${ }^{14}$ were close to pygmies in ancient painting: seeing them would immediately transport the viewer into an unreal, possibly comic, world which, if it might have had some connecting points with the real world, was nonetheless distorted and distorting.

From a methodological point of view, I will follow the path set during the last thirty years in iconographic research and 'theorized' by G. Sauron and P. Zanker in the mid-1990s. ${ }^{15}$ It will there fore be of primary interest to understand the frieze

\footnotetext{
"I have no doubt that under this disguise the owners of the houses portrayed on their walls the economic life of the city, and in part their own life. The most famous example, though not at all unique, is the well-known frieze of the 'black' room of the House of the Vettii (see pl. xiv and xv)" (Rostovtzeff 1957, 578).

9 "A small-scale frieze in the house's largest reception room (q) [...] has received undue scholarly attention" (Petersen 2006, 5).

${ }^{10}$ On the difficulty to follow traditional interpretations with respect to house occupants, see Allison 2001, 61-64.

11 D. Esposito, personal comment, 19 January 2015.

12 Allison 2004a, 185-186, following Mau 1896, 63.

13 J. Clarke $(2003,100)$ rightly highlights the frieze's visibility during banquet. However, the guests' reclined position would not have allowed them to rotate their head towards the closest part of the frieze that laid immediately behind them (see fig. 7-8 below).

${ }^{14}$ On Cupids' ambiguity, see Blanc \& Gury 1986, 953, 1047-1049.

${ }^{15}$ Although neither Sauron (1994, 11-15) nor Zanker (1994) consider their work as theoretical, their researches provides us with a broad theoretical framework for better understanding Roman iconography.
} 
from the respective views of the patron and of its ancient viewers. Schematically, the frieze would be the medium through which the patron aimed to convey a message to its viewers. Considering such an approach as original would seem ludicrous: the main interest of previous interpretations was to reckon the patrons, the supposedly freedmen Vettii, as Pompeian incarnations of Trimalchio and therefore likely to represent their successful economic activities on their walls for their guests to admire them. However, there is all too little evidence to support such a hypothesis; instead, we shall here follow the simple premise that the occupant(s) of the Casa dei Vettii belonged to the local elite and received other members of that elite in room q. Such a premise, thanks to the analysis of the frieze's iconography, should allow us to perceive any common culture between the patron(s) and the viewer(s): through the choice of such representations, the patron expressed 'something' that potential viewers would have been likely to understand. However, it should be emphasized that we should not assume that the subject matter depicted in the frieze directly reflects the commission of the patron. The painters, belonging to the so-called 'workshop of the Vettii',16 would carry out the commission but this was tempered by their own levels of expertise. As we shall see, whilst the patron appears to have expressed a general theme, part of the decoration derives from the interpretation of this by the painters.

There were three potential viewers of the frieze: the patron, the painter, and then the viewing guest or visitor. We will focus on the first two of these. Indeed, despite actual difficulties to access the house, it was possible to spend hours observing each scene in any of their details; most probably only the painters who made the frieze had been able to do so previously. This (far too) detailed vision, which will be the basis for the necessary description of each panel of the frieze, ought to be simplified in a second time to try to get not only the patron's, but more specifically the viewer's point of view. Going back and forth between a punctilious description and a broader vision will offer a comprehensive reading of the frieze and highlight the existence of a technical culture in the Pompeian elite through it.

${ }^{16}$ On the organization of this workshop, particularly in their decoration of the Casa dei Vettii, where two painters were active, see Esposito 2009, 49-54. However, the predella would have

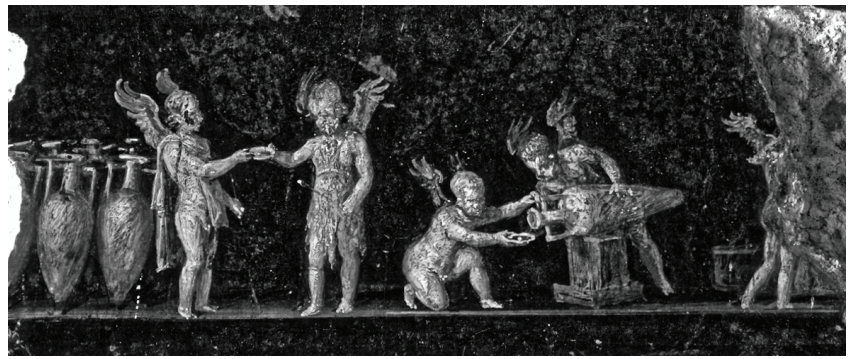

Fig. 1. Pompeii, Casa dei Vettii, room q, north wall; Cupids tasting wine.

\section{West Wall: Wine Tasting}

I will begin by presenting a description of each of the frieze panels. Starting with the west wall, this is particularly damaged, with only one scene that is still partially visible whilst both scenes at either end were irreparably damaged and cannot be made out. Previous readings of this scene have unanimously pointed towards wine retail or at least set in a shop. ${ }^{17}$ Yet the Cupids aside, [201] careful observation of the scene's other elements reveals a striking absence of realism (fig. 1). Only the central portion of the panel is preserved, which contains a scene that is divided into two parts. On the far right, a Cupid moves to the right, but it is impossible to determine what he is doing. Behind him, two naked Cupids are busy filling a patera with wine poured from an amphora that is horizontally tilted on a low stand. The amphora is of the same form as several further amphorae, propped vertically against a wall; all of them exhibit the characteristic shape of Dressel 2-4 wine amphorae. Between the amphorae and the patera-filling scene two standing Cupids exchange another patera with their right hand, each holding a stick with their left. It is, however, impossible to determine which Cupid is giving the patera to the other and also then which is receiving it and about to taste the wine. Particularly striking is their clothing, which contrasts sharply with that of the majority of the other characters of this panel, who are naked, and many of the other panels where all Cupids either wear a tunic or are naked. In this scene, the left Cupid is wearing a chlamys while the other wears a fur or hair coat, interpreted as a

been painted by the "Io painter" alone (D. Esposito, personal comment, 19 January 2015).

${ }_{17}$ Mau 1896, 83-84; Sogliano 1898, col. 363; Rostovtzeff 1957, 92; Clarke 2003, 105. 
nebris by A. Sogliano. ${ }^{18}$ The hairy character of this garment prohibits seeing it as a nebris in its literal sense, but it could also simple be a sign of slapdash work by the painter. The meaning of such a dress is clear though: the scene cannot be one of negotium where one of the Cupids would taste wine before buying it from the other; ${ }^{19}$ instead, in this scene, one of the Cupids, taking part in the thiasus, make the other taste wine before him joining the procession..$^{20}$ The next panel on the western wall has completely disappeared so, despite the strong Dionysian theme of this area in the room, we cannot speculate on the content of the other panels on this wall.

\section{North Wall: Thiasus, Grape-harvesting, Banquet}

For the present discussion, a detailed discussion of the three panels on the north wall is less problematical. ${ }^{21}$ On the left, five characters surround a carriage drawn by two goats; the scene reads from right to left, the characters moving towards the right. Leading the procession, a Psyche is perched on a panther. Behind her, two Cupids follow, one holding a long lit torch, while the [202] other, turned around, offers a vase to the goats to encourage them to drink. The carriage, which is driven by a Cupid, carries Bacchus/Liber reclining on a couch. The procession ends with Pan, ithyphallic and playing the flute, and a final dancing Cupid with a crater on his shoulder. The bacchanalian thiasus is under way, mainly composed of Cupids all of whom wear at least a cloak. The next panel now presents visibility difficulties due to its partial fading. It is composed of three parts. On the left, four naked Cupids bustle around a vine arbour; two perched at its top, a third readies a ladder to climb up, while a fourth is perched on a pedestal to gather the grapes. In the centre is a press lever and winch. Two Cupids cling to the manipulator arm to operate the device in a manner known elsewhere but here made comedic by the Cupids' desperate posture. To the right was likely a grape harvesting scene, which remains difficult to decipher because of its adv anced deteriora-

Sogliano 1898, col. 363. Only V. Sampaolo (1994, 563-564) and J. Clarke $(2003,105)$ have subsequently followed this interpretation.

${ }^{19}$ Contra De Angelis 2011, 67.

${ }^{20}$ To my knowledge, there is no parallel to this wine-tasting scene.

${ }^{21}$ For more detailed descriptions, see Mau 1896, 82-83; Sogliano 1898, col. 362-363. tion, even in the first photographs taken in the 1890s. Through technical culture, the panel only requires a single comment: this type of press would have been obsolete in the third quarter of the first century AD, by when, according to Vitruvius and Pliny, it had been replaced by lever and screw presses. ${ }^{22}$ However, they were still the norm in the wine installations of Pompeii and its surroundings. Therefore, while the represented press was not at the forefront of technical developments at that time, it formed a familiar image of wine production, further reinforced by the grape harvest occurring on both side of the pressing scene. The third panel on the north wall is also difficult to interpret in detail due to its degradation. In the centre, four Cupids lay on couches; Psyches coming from the left serve them whilst in the centre various elements of wine consumption, the crater, kyathos and skyphoi, can be recognised, while two donkeys stand behind the central group. This representation has almost unanimously been interpreted as the banquet that took place during the latter part of the Vestalia, celebrated by bakers on the $9^{\text {th }}$ of June. ${ }^{23}$ However, it should be noted that it is only the presence of the donkeys that strictly refers to this festival, although in this scene these have not been adorned with garlands of flowers, as we might expect. In a painting from the macellum, now lost, with a similar com position, the connection to bakers and therefore the Vestalia is clearer given the presence of a grinding mill behind the group of diners. ${ }^{24}$ The panel of the Casa dei Vettii could be an a daptation of the one from macellum, carried out by the same workshop..$^{25}$ However, rather than relating to the Vestalia, donkeys would accompany Priapus or Silenus in thiasus. Moreover, the general theme of this panel refers to the banquet, without any clearly established link to production.

\section{East Wall: Cupids and Psyches Preparing Clothes}

The panels of the eastern wall are the best preserved. The northernmost panel breaks with those already discussed that had a centred composi-

22 Vitr. 6.6.3 ; Plin. NH 18.317. See Brun 2003, 59, 60-61; 2004, 13-23; contra Rossiter \& Haldenby 1989, 233-237.

${ }^{23}$ Mau 1896, 80-81; Sogliano 1898, col. 360-361; Sampaolo 1994, fig. 135 p. 148; Clarke 2003, 101.

${ }^{24}$ Helbig 1868, nr. 777; Blümner 1912, 46, fig. 23.

${ }^{25}$ Esposito 2009, 85-86. 


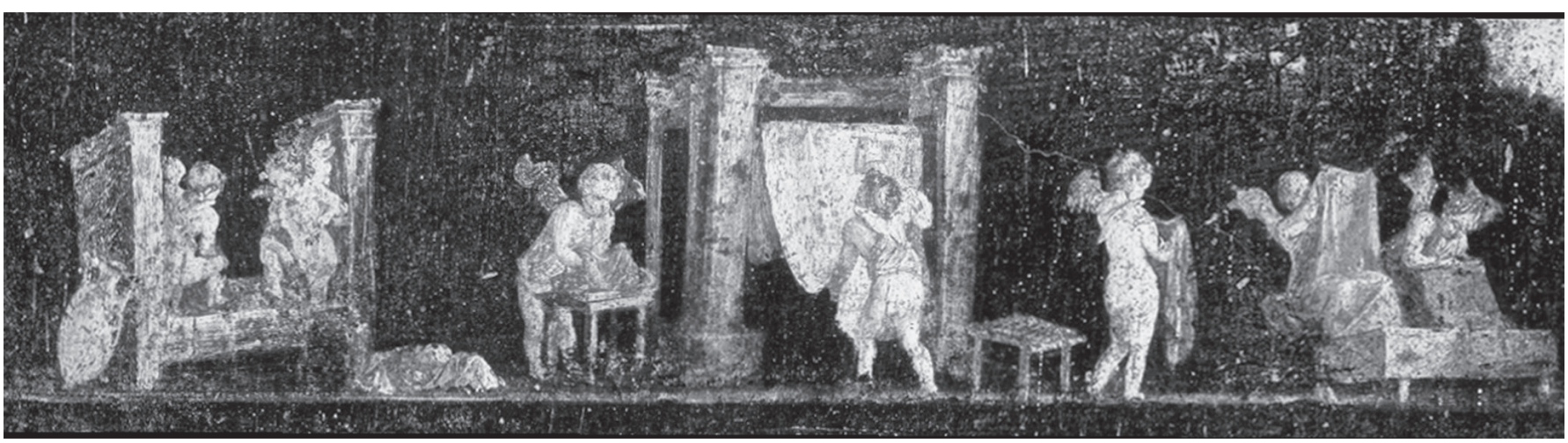

Fig. 2. Pompeii, Casa dei Vettii, room q, east wall; Cupids and Psyches preparing clothes.

tion; this panel was divided into three parts and seems to read from left to right (fig. 2). ${ }^{26}$ In the first scene, the principal element is a wooden structure, slightly raised from the ground and enclosed on its short sides by solid uprights surrounding a rectangular basin or vat. An amphora, identical to those depicted on the western [203] wall, leans against the left hand upright. In the vat, two Cupids face one another and, balancing on their left legs, they raise their right legs in preparation of treading with their right forearms pushing down on their raised leg to emphasize their movement and effort. The right hand cupid supports itself with its left arm on a short projection of the right hand upright. Had we only this portion of the panel, the interpretation of the scene as one of Cupids trampling grapes would have been obvious, thematically connected with the previous panels and additionally supported by the presence of the wine amphora. The only difference with this and later representations of this activity is that Cupids here do not hold hands while crushing grapes. In isolation, this scene can hardly be understood as an example of cloth fulling: nothing in the position of the two Cupids recalls the fullers at work as are represented on the fresco from the so-called fullery "of Veranius Hypsaeus", where all the fullers depicted are isolated in stalls, in a remarkable parallel with the workshop's remains. ${ }^{27}$ To facilitate the transformation of a scene inspired by grape

${ }^{26}$ Mau 1896, 79-80; Rostovtzeff 1957, 96. Uniquely A. Sogliano (1898, col. 358-360) describes this panel from right to left.

${ }^{27}$ Discovered in VI 8, 2.2021, this painting is now in the Museo Archeologico Nazionale di Napoli (MANN, inv. nr. 9774). See Fröhlich 1991, 229-236. See also the relief from Sens (Espérandieu \& Lantier 1911, 11-13, nr. 2768). Paleopathological treading into one of textile fulling, the painter managed to give the impression that there were fabrics beneath the Cupids' feet, while on the ground to the right, lie a pile of fabrics, ready for processing. The second scene in this panel also has two Cupids wearing tunics. The first one, on the right, is busy handling a piece of orange-coloured fabric on a table while the second one brushes a yellow dress lying between two wooden posts that comprise part of a larger structure. The Cupid holds the fabric with his left hand and brushes it with a brush in his right hand. In the fresco from the so-called fullery "of Veranius Hypsaeus", a figure adopts the same stance. Notwithstanding this unique parallel, this is the only part of the panel using the iconography of the fullery. To facilitate the transition to the last scene of this panel, another Cupid moves away from the wooden posts with a piece of cloth taken from a small table in hand. He carries it to three Psyches who are seated on two platforms, two on the left, and one on the right. Each of them handles dyed pieces of fabric, so as to view the quality of the work.

Overall, this panel does not represent a specific illustration or evidence for the history of technology. A detailed analysis of it does not reflect actual fulling practices. ${ }^{28}$ The first scene rather appears as an adaptation of a grape-treading scene, on the part of the painter, and only the central [204] scene finds a match with other representations of this activity. data, gathered from a study of the skeletons of individuals who had probably been fullers, reveals evidence for repeated arm movement of the kind required to work in treading vats, similar to those discovered in excavations (Catalano \& Musco 2011).

${ }^{28}$ Contra e.g. Monteix 2010, 195-197; Flohr 2013, 100, 104, $114-116$. 


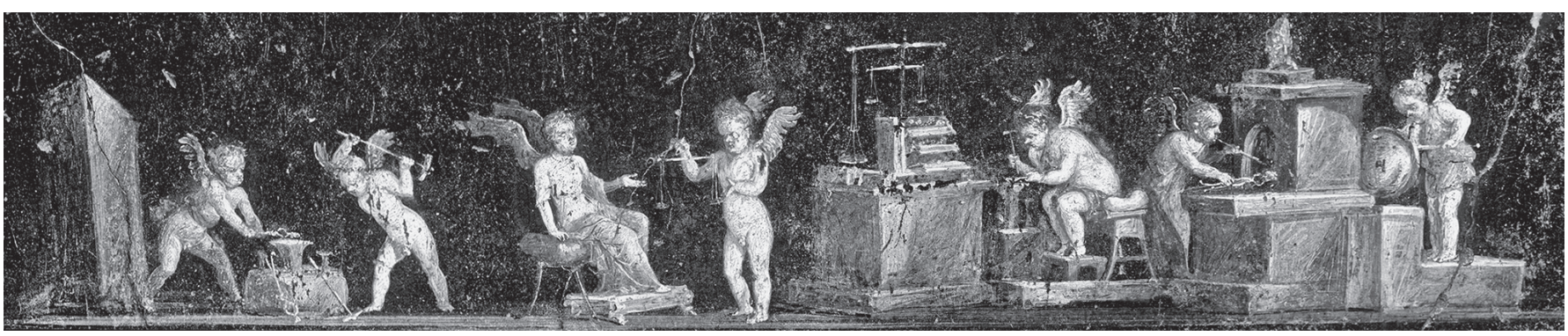

Fig. 3. Pompeii, Casa dei Vettii, room q, east wall; metallurgist Cupids.

Given this and handling of fabrics in each scene, or the suggestion of their manipulation, the illusion is achieved: that is of a scene generally presenting the preparation of coloured fabrics rather than a real or practical illustration of actual production. This suggests, therefore, the adaptation of compositional schemes by the painters in order to fulfil the patron's iconographic wishes.

\section{East Wall: Metalworking Cupids}

The next panel has been the subject of considerable attention but whilst the surviving images point to an exegesis of metalworking Cupids, conclusions derived from it have often been contradictory in detail. ${ }^{29}$ To avoid any teleology in the direction with which it was supposed to be read, I will describe this panel from left to right, before returning to a more general view (fig. 3). Two vertical features frame the panel, a cuboid on the left and a column, surmounted by a vase, on the right. These two elements appear to have no significance in the overall composition, except for filling in an otherwise blank space. The scene on the left shows two naked Cupids working at the larger of two anvils. The first one, on the left, holds a reddened piece of metal with pliers, while the second, on the right, brandishes hammer above his head with both hands, ready to pound the metal. A second pair of pincers and a second hammer lean against the anvil's stand. From a technical point of view, the posture refers to the working of hot iron. From an iconographical point of view, their stances

${ }^{29}$ The proposed interpretations are as follows: metallurgists (Sogliano 1898, col. 356-358) although the precise metal is undefined, goldsmiths (Mau 1896, 78-79; Rostovtzeff 1957, 96; Clarke 2003, 101), Cupids striking coins (Ely 1896) and jewellers (Tameanko 1990).

${ }^{30}$ See the so-called "boilermaker relief" (MANN, inv. nr. 6675; Zimmer 1982, cat. nr. 121), of which an analysis is given by M. Pernot (2011, 107-108). See also the altar of L. Cornelius are relatively common, often used in depictions of workshops where craftsmen work iron, bronze or even silver. ${ }^{30}$ The next scene depicts a Psyche, sitting on a possibly metal chair equipped with a cushion, with her feet resting on a crafted footrest. She offers her left hand to a naked Cupid who is showing her with his left hand an equal-arm beam balance, held with his right hand. The very small size of the scales does not allow us to see the objects placed on them; rather it suggests their diminutive size. In the third scene, a Cupid, apparently only wearing a red garment draped around his thighs and hips, is seated on a wooden chair with a cushion, the chair set on a platform. His feet are resting on a low stool and he holds a small hammer in his right hand and a clamp closed on a piece of metal, probably gold, in his left hand. Two small anvils are set out before him. Between him and the previous scene is a large piece of furniture supporting three shelves. On the two top shelves, one can see some small but indistinguishable golden objects. Behind the shelves, a vertical support accommodates two equal-arm beam balances, the empty scales of which are of relatively small size. ${ }^{31}$ The Cupid's posture here corresponds to a second variant of depictions of hammering activity, where the artifex works alone and is seated. ${ }^{32}$ In terms of metallurgical practice, this differs considerably from the first [205] scene; the work shown here is meticulous and most likely does not involve iron. Other painted elements in this scene also indicate work on small amounts of possibly valuable metal.

Atimetus (Musei Vaticani, inv. nr. 9277; Amarger 2009, fig. 2 p. 137; Zimmer 1982, cat. nr. 121), and two other examples (Zimmer 1982, cat. nr. 113, 115).

${ }^{31}$ One would not follow M. Tameanko $(1990,46)$ who considers the largest of the balances to be a magnifying lens.

${ }^{32}$ For other examples, see Zimmer 1982, cat. nr. 120, 122-124, 126. 


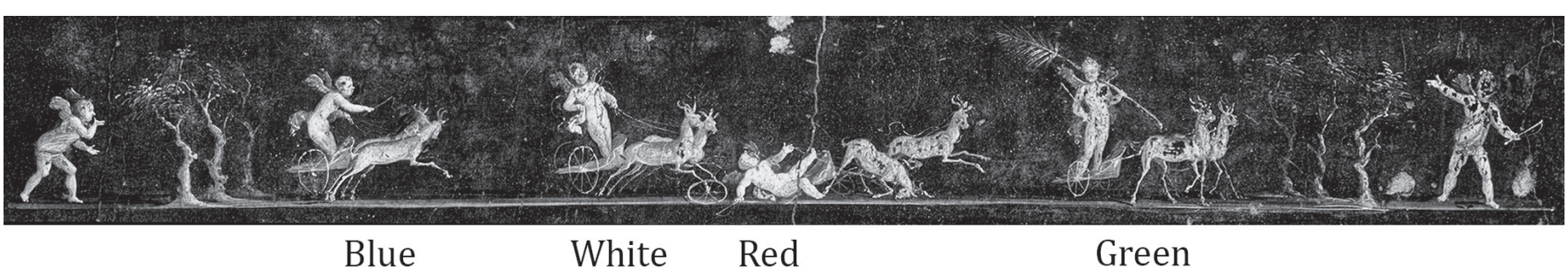

Fig. 4. Pompeii, Casa dei Vettii, room q, east wall; chariot-race scene.

The feature depicted in the last scene of the panel can be easily recognised but also shows signs of extensive iconographical reworking. Two Cupids, the mirror image of one another, are busy on either side of a furnace for metalworking, easily recognized by its mouth through which flames are suggested whilst a head of Vulcan is positioned on top. Both Cupids wear similar tunics ${ }^{33}$ and stand on a platform. With swollen cheeks, they blow into a pipe to stoke the embers. With the other hand, as we can only see for the Cupid on the left, they place a deformed object with a pair of pincers inside the furnace. A metal disc, forming the door to close the heating chamber, rather than a disk being worked, ${ }^{34}$ hides the hands of the Cupid on the right side. The scene here is at least inconsistent or unrealistic from a technical point of view: using their pipes simultaneously on both sides of the furnace, the Cupids blow heat towards the other! The composition of this scene also suggests that this proved awkward for the painter. Indeed, it is likely that Cupid on the left was added later to make the scene clear as otherwise it would have been difficult to understand: hidden by the door, the gestures of the Cupid on the right would have been obscured. This hypothesis could explain the astonishing structure of the furnace, the inversion of the shadows on it or the absence of separation by a blank space between the last two scenes on the right. Another hint that this proved less than straightforward for the painter is the fact that this panel is the only one that is not read in a linear manner, although neither is it strictly centripetal, like the grape harvesting panel. At the very least, linear readings fail to point at a specific chaîne opératoire. It is also impossible to determine a real

${ }^{33}$ The left Cupid's tunic is substantially longer. For this reason, Mau $(1896,78)$ considered it was a Psyche and not a Cupid. However, in comparison with other Psyches represented in the room, the nakedness of the right shoulder prohibits this activity for those metallurgist Cupids who mix iron and also work on precious metals. Such a technical view did not have yet the slightest importance for the non-specialist. Forgetting any pursuit of a realistic and linear chaîne opératoire, the scene reads in centripetal manner. The two side scenes generically display metalworking while the two central scenes reflect the nature of the work by inference: the metal is valuable because it is worked in small quantities and is intended for a Psyche. At the cost of distorting the technical reality, the painter achieved an impressionist effect but one that does not allow us to identify any specialization in their work nor does it support the interpretation of the panel in a positivist way [206].

\section{East Wall: Chariot-Race}

The panel in the centre of the eastern wall depicts a chariot race of which A. Mau gave the best description (fig. 4). ${ }^{35}$ Indeed, he is the first to draw a clear parallel between the panel and the facts known about circus races in Rome. Every element has simply been transposed: horses are antelopes; the three metae framing both side of the spina are trees, most likely olive trees. Each Cupid races in the colours of the Roman factions. The Cupid in blue, ueneta, faction is last, preceded by the one in the white, alba, faction. The charioteer in the green, prasina, faction wins the race, arriving first at the right end of the track and holding the palm of victory in his hand. The Cupid in the red, russata, faction was the victim of a naufragium; according to Mau, the head of the fallen antelope shows that the painter modified his initial work; the antelope was first painted falling, head forward, and was subse-

interpretation. Both Cupids appear to have 'feathered-wings' (see below n. 44).

${ }^{34}$ Contra Mau 1896, 79; Sogliano 1898, col. 356-357.

${ }^{35}$ Mau 1896, 77; Sogliano 1898, col. 355-356. 


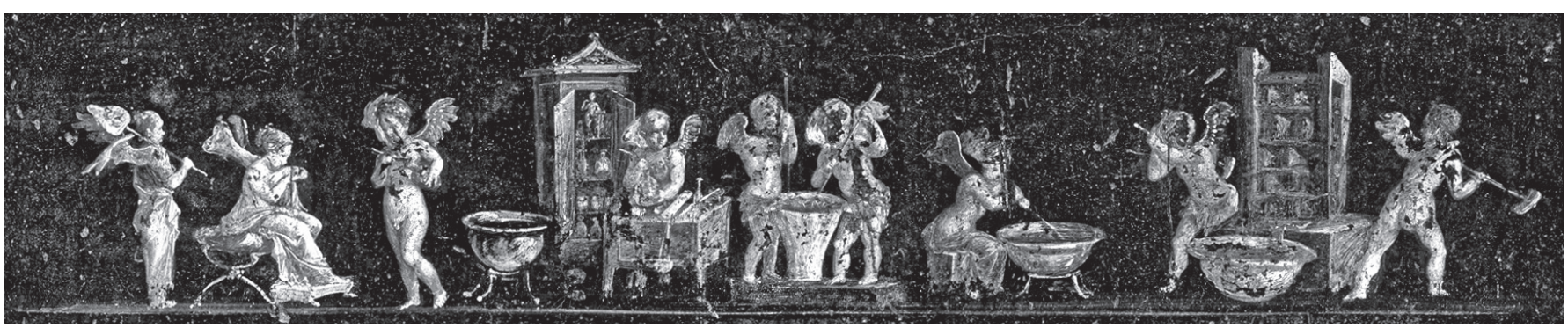

Fig. 5. Pompeii, Casa dei Vettii, room q, east wall; Cupids and Psyches preparing perfumes.

quently reworked, doubled over, with its head to the ground. At either end of the panel are framing trees beyond which, on each side, is a Cupid: the one on the left appears to be a spectator, thumbing his nose at the red charioteer; the one on the right holds a whip that could refer to the lanista. Whilst it is difficult to draw any conclusions from the reasons for the alteration of the antelope, the choice of the position for each faction's chariot, distinguished by their colours, is worth considering. The winning place given to the Greens while the last place is given to the Blues whose charioteer seems to have hardly started the race; this cannot be interpreted in the shadow of Nero's favour for factio trasina. ${ }^{36}$ Such a depiction can only derive from the direct influence of the patron's partisanship: being favourable to the Greens, the patron would have hated the rival Blues. ${ }^{37}$ Finally, one should note that the display of such a partisan passion does not necessarily refer to the values of otium, but much more to those of agôn, here expressed through a fundamental part of Roman culture, the circus games [207].

\section{East Wall: Cupids Preparing Perfumes}

The fourth panel on the east wall is divided into five scenes that read from right to left (fig. 5). Besides the reading of each of these scenes, it is worth noting that all them have parallels elsewhere, some differences of detail aside.

On the right, two Cupids stand on either side of a press wedge set on a stone base. Each cupid

${ }^{36}$ Sampaolo (1994, 554, fig.145) uses the supposed submission of the patron to the emperor's preference to date the paintings before 69 AD. However, Vespasian's preferences for any factio remain unknown.

${ }^{37}$ On the early polarization of partisanship between the Blues and Greens, see Cameron 1976, 53-56.

${ }^{38}$ For an exhaustive list of the various interpretations made on this part of the painting, see Mattingly 1990, 72-74. swings a hammer while a golden liquid flows from the press into a metal container. The extraction of oil is without doubt. ${ }^{38}$ However, the proliferation of similar representations of pressing with this device and their similarity highlights three issues. First, notwithstanding the current debate between D. Mattingly and J.-P. Brun regarding the form of the frame used to operate wedge presses, there is considerable variety in the form of the extant depictions. ${ }^{39}$ Second, they also highlight the lack of a single model, such as a sketchbooks, ${ }^{40}$ and so the work of painters was mainly based on memory. Third, the kind of press used by the Cupids in the Casa dei Vettii painting does not correspond to those in use in perfume workshops of the Vesuvian area at the time of the eruption; judging by examples from Herculaneum, Paestum or Pompeii screw presses seem to have replaced wedge presses. ${ }^{41}$ The next scene is where we see a seated Psyche mixing the contents of a metal container with two sticks. The container is set on a tripod in front of her and refers to the enfleurage of oil. However, it should be noted that in this case no flame or fire is depicted yet the suggestion of heating the container nonetheless comes to mind because of the use of a tripod, similar to those used in domestic kitchens. This distortion, in a globally consistent drawing from a technical point of view, is also visible in a painting from the Casa dei Cervi from Herculaneum where the depicted domestic metal stove is very far from the masonry stoves used in Pompeian perfume work-

\footnotetext{
${ }^{39}$ Doubts have also been expressed about the reality of these depictions, see Mattingly 1990, 79-80; contra Brun 2000, 294-295.

${ }^{40}$ P. Bruneau $(1984 ; 2000)$ has similarly argued that Roman mosaicists worked from memory and so did not use sketchbooks. The same conclusions can, on this basis, be drawn of painters.

${ }^{41}$ Brun \& Monteix 2009.
} 
shops. ${ }^{42}$ To the left of the seated Psyche, two Cupids stand on a small platform, each of them holding a long and thin stick in a non-metallic container. Only the posture of the Cupid on the left suggests the grinding of the ingredients necessary to prepare perfume. However, the represented instrument is really too small to grind anything, just as in a similar scene in a fresco from the Casa di Trittolemo at Pompeii. Both are quite different to a more convincing depiction of grinding that appears in the scene from the J. Paul Getty Museum. ${ }^{43}$ Further to the left, another Cupid, possibly seated, is behind a table on which are arranged various instruments including a possible papyrus roll, a bottle and a ladle. He holds in his hands a transparent bottle whose shape is similar to a number of further bottles stored behind him in an open cabinet. On the top shelf of the cabinet stands a small statue, generally interpreted as Venus. This representation has direct parallels, with some small differences of detail, both in the fragment of the J. Paul Getty Museum, where only the furniture is painted, and in the one from the Casa di Trittolemo. In the latter, the interpretation of a counter is clarified by the rear perspective of the scene: in front of a Cupid is a client Psyche trying perfumes. In the Casa dei Vettii, this part of the scene [208] is on the far left. Between the 'counter' and the final scene, a metal container on a tripod stands alone. In the final scene, on the far left, a Psyche, wearing a dress, sits on a metal seat topped with a cushion. Her feet are on a footrest while she holds her left arm with her right arm and her head is bowed towards her left arm. Before her, a Cupid holds a bottle under his left arm from which he is extracting a small rod. The fragment in the J. Paul Getty Museum replicates this scene of perfume testing with identical and mirroring postures. The only difference between the two is the addition of a waiting Psyche in the Casa dei Vettii panel who stands behind the 'client' Psyche; she wears a long dress and holds a fan on her right shoulder. I would stress that this panel focuses on perfume, at various stages, from production to testing the final product. Some elements

\footnotetext{
${ }^{42}$ For an example of such a domestic iron stove, see Kastenmeier 2007, fig. 61 p. 80

${ }^{43}$ For the painting from the Casa del Trittolemo, see Trendelenburg 1874, 46-47, pl. 3.2b; Mattingly 1990, 74-75, fig. 3. The fresco fragment with Cupids and Psyche making perfume is in the collection of the J. Paul Getty Museum (Inv. nr. 72.AG.81).
}

in the panel deviate from those observed in perfume workshops at the time of eruption, such as the wedge presses instead of screw presses, or the use of domestic tripods for the enfleurage of oil. Furthermore, the existence of four to five other examples of the same scene, although with significant differences between them, suggests the scene in the Casa dei Vettii cannot represent a bespoke commission carried out at the request of the patron: rather, the painter adapted his repertoire to the patron's general requirement.

\section{East Wall: Cupids and Psyches Handling Garlands}

The last panel on the eastern wall is divided into three little scenes that seem to read from right to left (fig. 6). On the right, two Cupids, one in front and one behind, guide a goat on whose back a packsaddle is full of gathered but undistinguishable red items. The same red objects emerge from a basket that is carried with a stick by the Cupid on the right. In the central scene, however, these appear to be garlands of flowers. These are poured from a basket, or a beige bag, onto a table supported by two white, possibly marble, trapezophoroi in the form of griffins. A naked Cupid behind the table retrieves the garlands one by one and gives them to a second Cupid who is also naked. Between this scene and the next is a Cupid, leaning forward, who seems to handle one of these garlands, although a break in the painting prevents us from clearly determining what he is doing. ${ }^{44}$ In the last scene, two Cupids and two Psyches are working around a rack on which hang garlands. The first Cupid-Psyche duo, on the right, work together in suspending the garlands. On the left, while the second Psyche unhooks a wreath to place it on a plate, the second Cupid turns his head in her direction. He gestures to her with his right hand, his little and ring fingers closed, his middle and index fingers stretched apart and his thumb tucked up into the palm with a gamma shape. Contrary to the interpretation proposed upon the discovery of the fresco, and largely maintained since, this panel represents neither making nor the selling of garlands. ${ }^{45}$ Four

\footnotetext{
${ }^{44}$ Contrary to Mau (1896, 74), the depicted character cannot be considered as a Psyche given the Cupids in these panels are painted with feathered-wings, whilst the Psyches have membranous wings.

${ }^{45}$ See the first interpretative descriptions by Mau (1896, 73-74) and Sogliano (1898, col. 350-352) which have been since followed
} 


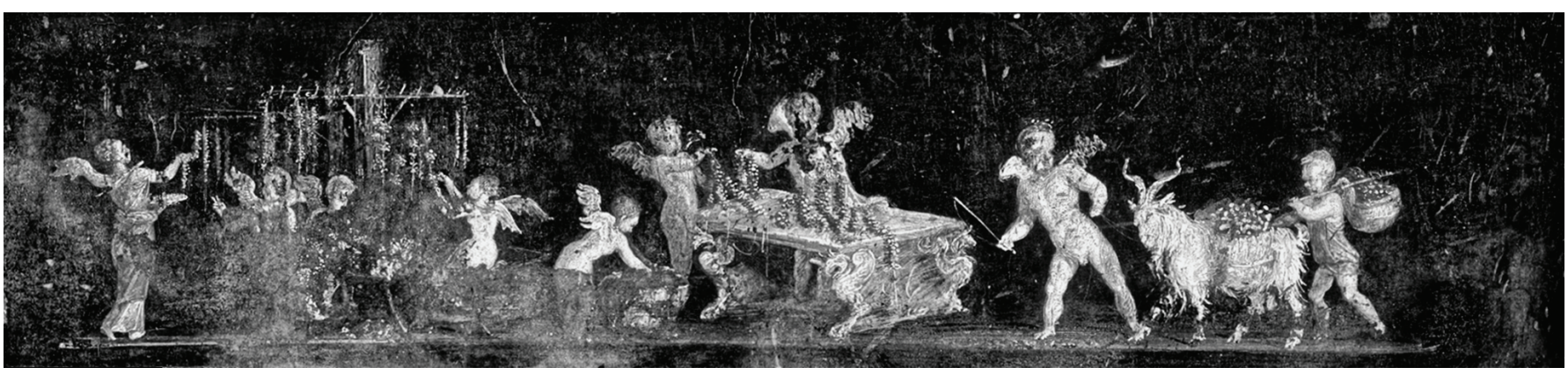

Fig. 6. Pompeii, Casa dei Vettii, room q, east wall; Cupids and Psyches handling garlands.

other scenes, three of which are only known by $19^{\text {th }}$ century engravings, show us the various steps in the production process. ${ }^{46}$ In each of those, Cupids are depicted as sitting around a table above which is a rack from which hang strings around which flowers are to be attached. In the [209] Casa dei Vettii, however, the last two scenes show garlands that have already been made. Unless we suppose that there has been a temporal gap between the first scene of the Cupids leading a goat, and the other two, we cannot determine whether the packsaddle was intended to contain flowers rather than finished garlands. This aside, significantly, the preparation of the garlands themselves remains absent.

With respect to the suggestion that the central scene might depict an act of sale, this is unsupported by the two Cupids; both are naked and nothing of their posture suggests that either is a client. Moreover, the particularly detailed trapezoforo $i$ in the forms of griffins, sets the scene in a domestic context rather than a commercial one. In contrast, in the scene on the left, the sign the Cupid makes to the Psyche, draped in her dress, suggests a sale where the Cupid is indicating a price of two asses. ${ }^{47}$ From G. Minaud's work on finger counting, the sign made by Cupid with his right hand should indicate the number fifty-two. ${ }^{48}$ Given the precision used in depicting this sign, which is clearly visible against the black background, and the specificity of the sign itself, we can neither assume that this is a coinci-

with little scrutiny. However, Guillaume-Coirier (1995, 1108-113) stresses the lack of any imagery relating to production in this scene.

${ }^{46}$ These paintings come from Herculaneum (Roux \& Barré 1839, vol. 3, pl. 146), from the macellum (Roux \& Barré 1839, vol. 2, pl. 84) and from the Casa di Trittolemo (Trendelenburg 1874, 47-48) at Pompeii. The fourth panel, without provenance, is in the J. Paul Getty Museum (Inv. nr. 72.AG.82). dence nor consider it as representing price of two a sses. I would cautiously follow Minaud's interpretation which links this figure to the number of weeks in the year and thus potentially to the cyclical nature of events. One final point needs to be emphasized on a significant choice made in this panel: besides the fantastical nature of mounts by the Cupids, that is antelopes, dolphins, lions, etc., the choice of a goat as a pack animal alludes to Bacchus and therefore, by association, to the banqueting held in the room.

\section{South wall: Cupids playing (?)}

Both of the jambs on either side of the southern doorway, through which one looks onto the peristyle that was adorned with a garden and fountains, has a panel with further Cupids. ${ }^{49}$ On the eastern side, the panel's scene is delimited on its left by a vertical post. In front of it, a Cupid rides piggyback on another, raising his arm back, as if to indicate a race start. To their right stands a Cupid who throws a ball or stone with his right arm so as to bounce it off a low post [210] to then hit a target board; a fourth Cupid adjusts this which rests against a large quadrangular post. Behind it, a fifth and final Cupid is watching the scene, appearing to sob and wipe a tear from his cheek with his right hand. The depiction of this ball game is one of a great variety attested in ancient iconography. The goal could be here to hit the target after a rebound off the central post; if one missed, they would pass onto the next obstacle and

\footnotetext{
${ }^{47}$ In the fragment in the J. Paul Getty Museum a Cupid makes the same sign to a Psyche who holds a plate.

${ }^{48}$ Typically, this numeral, composed of tens and units, should be made with the left hand. In this case, the Cupid's left hand is otherwise occupied so he indicates the numbers with his right hand. See Minaud 2006, 21-28.

${ }^{49}$ Mau 1896, 73; Sogliano 1898, col. 349.
} 
target a possible version of ephedrismos but without the player being blindfolded. ${ }^{50}$ This again highlights the agôn, in a form that is more c losely Greek than before. This childish form could also be a caricature of the shooting com petition, with a bow, without dismissing the extensive participation in ball games, including among the elite. ${ }^{51}$ The last panel, on the western doorjamb, is more difficult to understand because of its poor preservation, although it could relate to the same agonistic theme. Only Mau has proposed a quick description of this scene: that is of a Cupid who holds a duck under his arm; while a second Cupid, facing him, appears to ready himself to catch the bird in case it broke free. ${ }^{52}$ Such a scene remains, to my knowledge, unique. ${ }^{53}$

\section{Discussion}

During this long analytical description, we mainly took the viewpoint of the painter, following every detail of the rich compositions used for the predella in room q. Besides highlighting the remarkable quality and finesse of these panels, it has also highlighted the competence of the painter, particularly his ability to correct his own work where small errors were made. Overall, these paintings suggest the use of known patterns, which were occasionally adapted to better fit into a more general scheme. The two most prominent examples here are the transformation of a grape-treading scene into a fulling scene and the adaptation of the metalworking scenes to make them more readily understandable. Some of these adaptations seem to have been driven by the client's wishes. This is probably true of the choice of colours in the agonistic panel depicting circus games. Such an intervention, concerning a simple point of detail, at least in the overall decorative scheme of the room, emphasizes a high degree of coordination between the client and the painter in the implementation of the decoration. However, the client's interventions do not appear to have extended to issues of technical detail, suggesting he was either uninterested in them or understood them only superficially. The unrealism of the jumpy fullers, the aberrant mix of metallurgical techniques, the ineffective

\footnotetext{
50 On the different forms of these games, see Reinach 1892; Picaud 2004, 53-54.

${ }^{51}$ Hor., Sat., 1.5.48-49.

52 Mau 1896, 73.

${ }^{53}$ It is worth noting the similarity between this scene and the two statues of Cupids in the peristyle that formed part of a fountain. The statues flank a basin positioned on the central axis of room $\mathrm{q}$ and are the mirror image of one another, each with
}

furnace or the obsolescence of the wedge press are all subtle elements that appear to be inconsistent with the self-aggrandisement or pride of the client be he a fuller, a goldsmith or a perfume-maker. To judge these scenes in a wider artistic context we might consider the shop signs and other frescoes from Pompeian workshops. These were generally less competent works than those in the predella under examination but bear a striking accuracy in the technical elements included, suggesting the importance and pride therein to the commissioning client. In this context, it seems unlikely that a skilled craftsman-client, such as proposed commissioner of these works in the Casa dei Vettii, would have accepted apparent [211] in-accuracies in the, albeit fantastical, representations of 'his' workshops. Nor does anything in these paintings refer to the second trend in representations of craft, where the contractor appears as the donneur d'ordres, such as can be seen in Eurysaces' tomb next to the Porta Maggiore in Rome. ${ }^{54}$ The use of the Cupids and Psyches to depict these activities allows a certain standardization of characters and thus prohibits the possible representation of actual individuals. The only scene where this was not the case concerns the two uniquely dressed Cupids on the west wall, further distinguished from one another by their different garb. Yet, as has already been noted, this can neither represent a scene of negotium nor one taking place in a shop. Therefore, the different scenes in this room cannot represent the actual activity of the commissioning client.

None of these scenes betray the technical culture obtained through the patron's economical practices. It is accordingly important to try to understand the reception of these scenes from the point of view of the observer and to assess the ability of the latter to understand the message of the patron. It is therefore important to identify his physical visual field and to consider the various supposed production scenes in the broader context of the room's iconographic program.

To understand the point of view of the observer, we must consider the room's use. The absence of

a duck under his arm. A waterspout in each of the ducks' beaks provided a jet of water, while each cupid also holds a bunch of grapes in their other hand.

${ }^{54}$ On the two types of contractors that appear in representations of craft, the 'assisted expert' and the 'prime contractor' (donneur d'ordres), see Tran 2013, 116-144, with details on Eurysaces' tomb on p. 140-144 
any objects or furniture at the time of the eruption prohibits any positive interpretation. ${ }^{55}$ Despite the Latin terminology applied to this room by Mau that is an oecus, we will consider, mainly because of the architectural layout, that this was a reception room, the largest of those opening onto the peristyle. It is not a leap too far to consider banquets were given there, to which the guests participated on couches arranged in a $\Pi$-shape around the room, according to the Roman practice of dining, to which we shall return. The decoration of this room, including the predella, forms a truly coherent body for this form of conviviality that could symbolize otium in itself. ${ }^{56}$

One issue we face is reconstructing the individual's view whilst dining; this was, of course, unique to each guest. Given the dimensions of the room, the $\Pi$-shape layout of the couches could be arranged in three configurations, depending on the number of individual couches used; three or six. ${ }^{57}$ These configurations would thus position the guest at varying distances from the frescoes. Before settling on the couches, which we will assume were set in a central position relative to the room the diners would have taken in their surroundings and the overall decorative scheme. However, this would have been impossible if they took their places from the centre of the room rather than from around the edges by closely passing the walls. Whilst the loss of the principal elements does not permit us to elucidate entirely the core of the iconographical program, what survives provides some clues. In the middle zone, pairs of satires and maenads float on a red background, framed by fine golden columns that stand out against the black background. In the upper zone, satires and maenads also populate frons scaenae architecture. As for the lower zone, which comprises the base

${ }^{55}$ On the distribution of artefacts in this house, and particularly in room q, see Allison 2004b.

${ }^{56}$ The association between the banquet and otium has been underlined by several studies on the Roman banquet (see especially, Roller 2003, 380-384; Nadeau 2010, 401-404). However, F. De Angelis argues the case for the opposition between otium and negotium in the Cupid scenes (De Angelis 2011, 67).

${ }^{57}$ This was calculated using the dimensions of the couches from Herculaneum as presented by S. Mols, not- withstanding the difficulty in identifying these as beds or couches. On average, the couches are $2.15 \mathrm{~m}$ wide and $1.15 \mathrm{~m}$ (Mols 1999, 37-38, 124-127); for their height, see below n. 60 .

${ }^{58}$ Wyler 2004, 941. It is possible that the sadly missing panel paintings of the main zone were of a different subject matter and theme to the Dionysian-themed elements discussed here. If this and the predella, this would have been barely visible even when moving around the room, but even more so when the couches were deployed. The [212] predella were significantly more visible than the base, although scrutiny of the details, such as that as we have considered here, would have been considerably difficult. The first overall impression of an observer would be that of a highly Dionysian world, or at least one permeated with a form of cultural Dionysism, in which only the banquet remains, but allowing "a temporary assimilation [of the guests] as members of thiasus", in the words of S. Wyler. ${ }^{58}$

During the meal, the guests were reclined on the couches, propping themselves up with their left arms. Their field of view was thus significantly affected. The couches' arrangement in a П-shape seems to have been set by the end of the Republic and remained fashionable for at least the first two centuries of the Empire. This arrangement posited the two most important places: the place of honour, the consularis locus, located imus in medio, with the host next to him, summus in imo, corresponding to the left corner. ${ }^{59}$ In our room, this position would correspond to the north-western corner. Thus arranged, each guest could easily see the frieze behind the other guests that they faced (fig. 7-8). The visual field, which changed depending on the layout of the couches and the position of each guest, was best suited for viewing the frieze, because of its lower position. ${ }^{60}$ However, one part of the frieze remained invisible to each guest given its non-centrality with respect to the banquet, that is the section behind each guest. To view it clearly and in detail, each diner would have to turn to face the wall, turning his back on the other guests. On the other hand, the elements located behind a guest were more visible to

were the case the Dionysian theme would have remained, albeit of secondary importance.

${ }^{59}$ Dunbabin 2003, 38-43.

${ }^{60}$ The legs of the couches from Herculaneum did not survive so we are unable to determine the exact height at which the banqueters ate. However, the Niccolini brothers' reconstruction of a wooden couch with bronze legs, discovered in VII 2, 1819.49, sets the bedframe at $0.41 \mathrm{~m}$ from the ground. This is therefore lower than is cited in a recent study of bronze legs discovered in Avenches, in which heights vary from 0.55 to $0.65 \mathrm{~m}(0.99$ $\mathrm{m}$ for the legs from the Madhia shipwreck), see Duvauchelle et al. 2012, 59-61, fig. 59 p. 57. To these, it is necessary to add the thickness of the mattress and the approximate height (ca. $50-60 \mathrm{~cm}$ ) of a reclined diner. The frieze in room q of the Casa dei Vettii is situated between 0.95 and $1.20 \mathrm{~m}$ from the floor. In the presented reconstruction (fig. 7-8), the couches (including mattress) are $0.50 \mathrm{~m}$ high. 


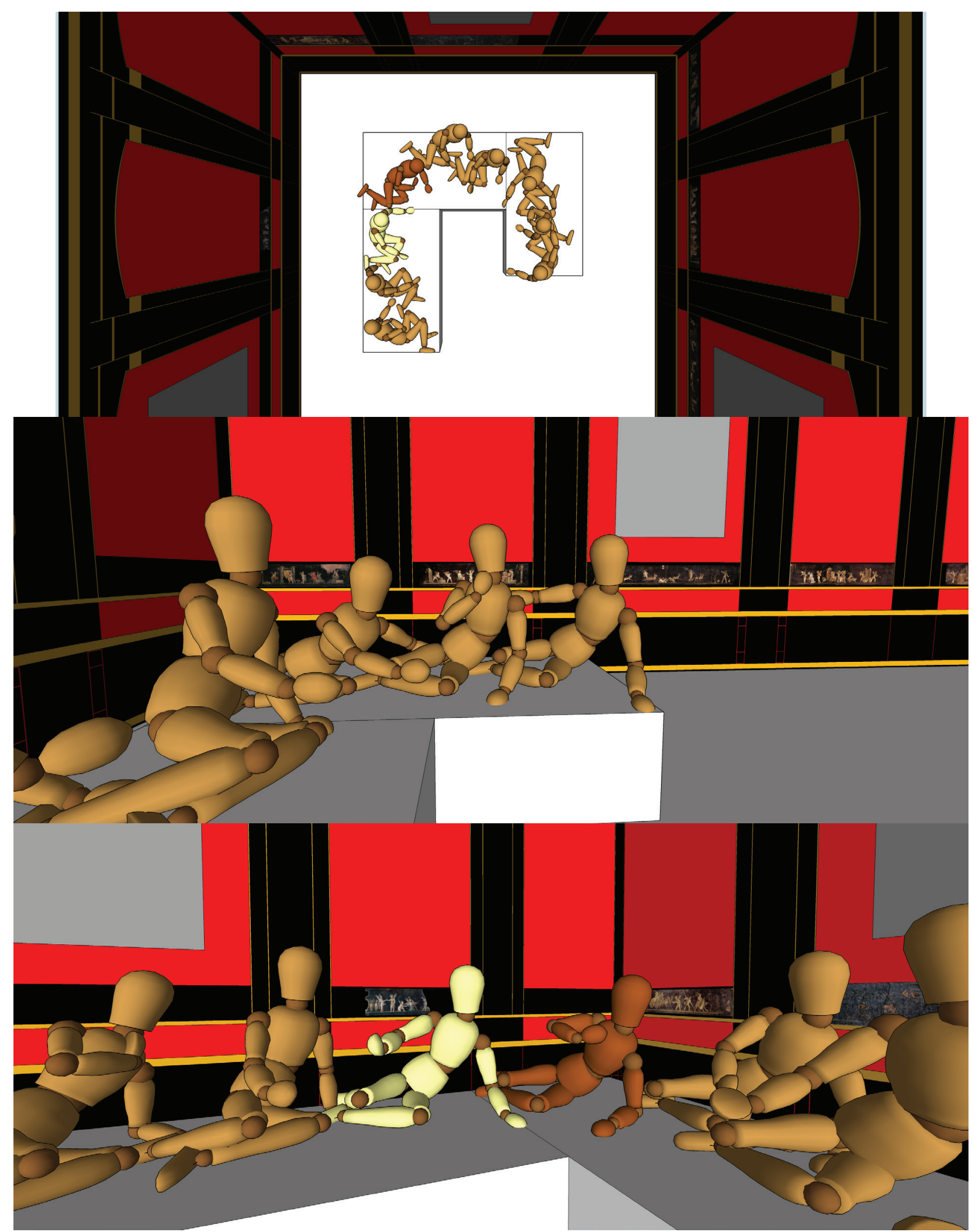

Fig. 7. Casa dei Vettii, room q during a banquet (from top to bottom): layout of three couches; view of the banquet from the locus consularis; view of the banquet towards the locus consularis [215]. 


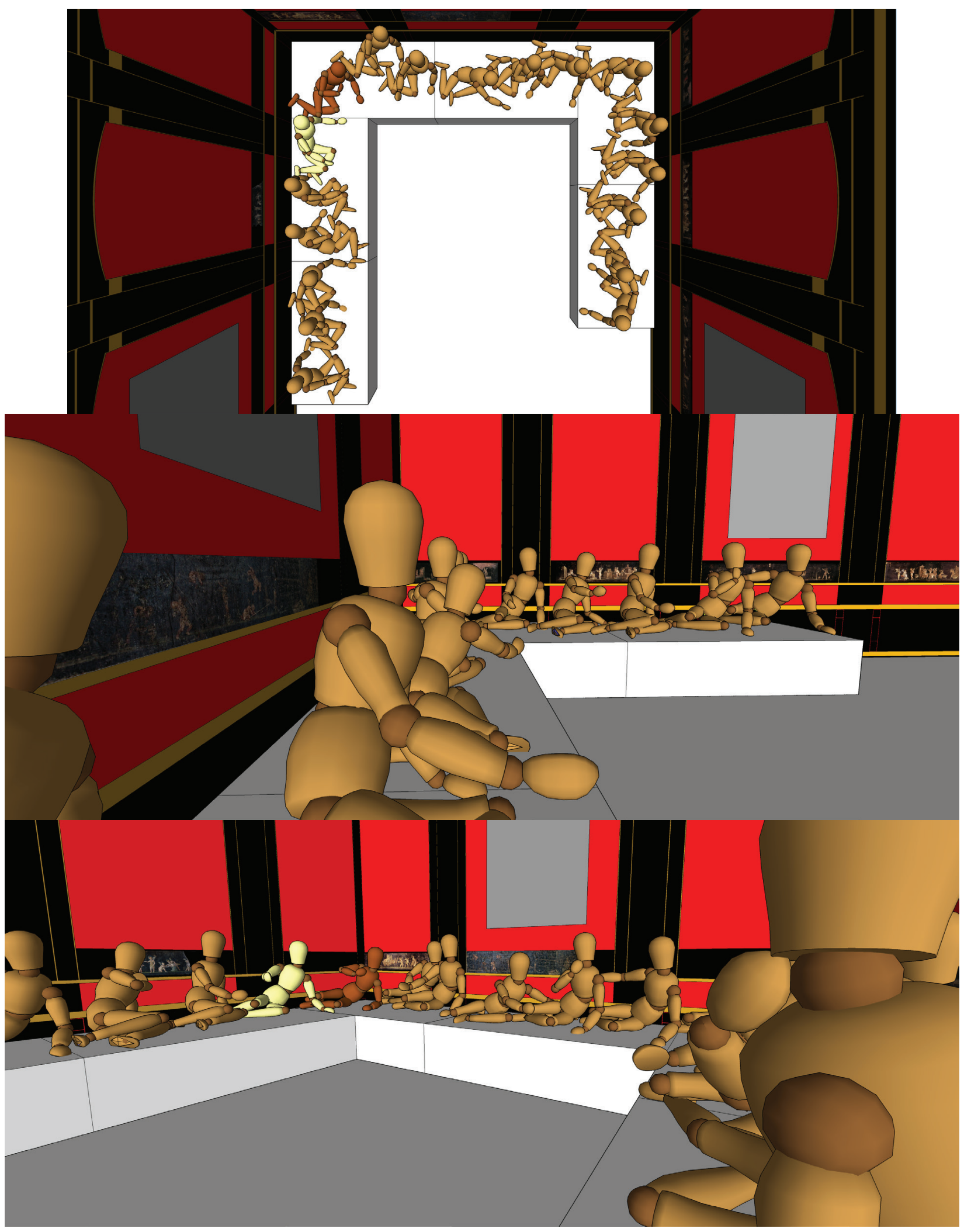

Fig. 8. Casa dei Vettii, room q during a banquet (from top to bottom): layout of six couches; view of the banquet from the locus consularis; view of the banquet towards the locus consularis [216]. 
those around him. Considering this and the placement of the most important positions at the table, the frieze with the Cupids may have held a dual role. That of a thematic caption for the guests, especially those located in places of honour: so, whatever the observer's position, in any arrangement, the occupant of the locus consularis would be associated with the thiasus or the grape-harvest. In this way, he would always lead the banquet. The second role of the frieze may have been to delimit the decoration visible at the time of the banquet, with its upper limit populated with Cupids thematically linked with the banquet and its preparation.

If the distance restricted one's ability to view every detail of the fresco, despite the low position, the application of colour permits shapes and most of the Cupids' gestures to be clearly perceived. With their typically white bodies, the latter stood out lucidly against the black background. The use and contrast of colours in other elements in the scheme allowed them also to stand out more clearly and be more easily understood. For example, in the wine-tasting scene, the wine is immediately recognizable thanks to the shape of the amphorae, while the addition of a garment to the two main Cupids stresses their connection with dining preparation. The thiasus panel is recognized as such not only through the postures of the different characters surrounding the chariot, but also thanks to the contrast of the satyr's coat to that of the Cupids. The [213] partisanship of the client is instantly recognizable through the coloured cloths set around the charioteers' shoulders. These three panels would have been broadly thematically identified through the cultural assimilation of representations of Dionysian scenes or circus games. The same goes for scenes set in a context of production: the guests' low technical understanding of the work depicted allowed them to recognize general technical scenes that, by association, permitted them to decrypt the broad meaning of the panel. The poor preservation of the central panel on the north wall prevents us from elucidating the colours employed, but the actions of the Cupids allow their activities to be understood. For example, in the centre, two Cupids operate a press for crushing the fruit whilst others, perched on poles, harvest the grapes, to then be crushed. They thus ultimately work to prepare the wine to later be consumed at the banquet. In the "fullery" panel, the eye follows, with remarkable ease, the different states of the fabric pieces thanks to their bright colours, first heaped, then hung out and eventually folded. The treading scene broadly borrows its iconography from scenes of wine- making; despite this, the scene, even viewed alone, is consistent with the preparation of the clothes for the banquet. The use of non- functional technical elements can also be observed in the metalworking panel. The reclining observer was unable to distinguish details in ironwork or inconsistencies in the depiction of the furnace perhaps because of his limited technical understanding of their workings. However, the two scenes flanking the panel immediately recall metalwork, thanks to the characteristic postures of the Cupids. The two central scenes in the same panel complement this theme visually, although not technologically, through reference to small amounts of metal, thereby suggesting their preciousness. The metal-working Cupids produce precious objects used for adorning the guests at the banquet as do the "perfume-makers", albeit with a different composition. The two final scenes give the general sense of the panel: that this press represents olive oil production rather than wine was indicated to the viewer by both the type of press depicted, as opposed to "Cato's" press that was used icono graphically to represent wine production, but also by the posture of the Cupids, rather than a technical understanding of the workings of such installations. In the scenes of perfume production, the testing of the perfume reinforces the subject matter, in case this was not already clear to the viewer. The central scenes complement and reinforce this evocation, technical inconsistencies aside. In addition to their finery, their clothing and jewellery, the diners also wore fragrance. The prepared garlands in the last panel on the eastern wall are immediately distinguished by their bright red colour. The fact that these are already complete and have been hung out rules this out as a scene of production. Their presence rather refers to the Dionysian and religious theme of the banquet. All the scenes of the predella therefore reflect the banquet as a whole, from its pre paration to its performance, albeit represented through the medium of Cupids and Psyches. Moreover, it not only includes Dionysian elements but also demonstrative references to the culture of the Greek banquet, through the agôn or iconographical quotes of Euripides. ${ }^{61}$ [214]

\footnotetext{
${ }^{61}$ Four scenes extracted from Iphigenia in Aulis and from Iphigenia in Tauris are depicted beneath the candelabras/ columns used to divide the panels. Their visibility seems to have been poor because of their very low position. However, they are thematically consistent with the patron's iconographical scheme.
} 


\section{Epilogue}

In conclusion, a detailed analysis of the scenes depicted on the predella allows a better understanding of the coherent iconographic program developed in the q room in the Casa dei Vettii. The change of views highlights the existence of a technical culture whose variable consistency depends on the eye used. Nothing here points to the self-representation of the client or a nostalgic nod to his former occupation, which remains uncertain. Despite their apparent eclecticism, the scheme indicates a reinterpretation of the Greek banquet, strongly marked by Dionysian ideals. Other elements also reflect a demonstration of Greek culture. In this collection, the $\mathrm{C}$ upids' frieze mirrors the banquet taking place in the room, in a distorted way. While all centred to the friendliness of their meeting, an otium practice, guests viewing these scenes are de facto released from any economic or productive concern. For the banquet to take place, it must first have been prepared: the panels illustrate the whole process, from preparation to celebration by evoking very generic scenes. Seen from the present-day, the paradox of this set, chosen by its patron, is that the painter, through his expertise, made the scenes that were not intended to be observed with such a degree of accuracy appear realistic. In previous works on these scenes, the effets de réel achieved by the painter have taken precedence over the general meaning of the whole decoration program. Yet the iconography employed, known from other examples, and their adaptation according to the painter's needs achieved a technically non-functional representation, in some cases bordering on the absurd. Any positivist reading should therefore be abandoned; as must be any absolute opposition to the relationship between the representation of technical aspects of production in art and the Roman elite. There is no need to justify the use of such scenes, which are firmly set in a dining context, by arguing that these panels cannot be more than a showcase for the economic and social success of the owners. Instead, the necessary understanding of these scenes by their observers stresses the existence of a diffuse technical culture among the elite, in stark contrast to the distrust and dislike vis-à-vis commercial activity by the elite as understood from Roman literary sources. We therefore need to take a less schematic view on the relationship the Roman elite with the economy: having an understanding of technical or working practices does not automatically reflect active participation in that economic activity.

\section{Acknowledgments}

Figures 1-6 were made on concession of the Ministero dei Beni e delle Attività Culturali e del Turismo - Soprintendenza Speciale per i Beni Archeologici di Pompei, Ercolano e Stabia. No reproduction or duplication can be considered legitimate without the written authorization of this Soprintendenza.

The idea of this paper goes back to a conference held in Rome in 2009, during a dis cussion following M. Pernot's paper (see Pernot 2011). I am most grateful to the audience both in Rome and then in Marburg for discussing these ideas. During the writing of this paper, many friends and colleagues offered me their advices and criticisms. I wish to thank A. Dardenay, A. Duvauchelle, D. Esposito, M. Pernot, E. Rosso and S. Wyler for their useful comments; last, but not least, J. Andrews for kindly reading and correcting the English text. Any errors or omissions remain my own. [217]

\section{Synthesis}

As soon as its excavation was over, the house "of the Vettii" in Pompeii amazed archaeologists and art historians for the quality of its paintings. Beyond chronological problems, comments particularly arose out the observation of a frieze notably representing Cupids and Psychai at work. Having openly or not in mind Petronius' Satiricon and his outrageous caricature of enriched freedmen on one side, and the alleged incompatibility between 'traditional' elites and urban production on the other side, most commentators linked the choice of such a theme to decorate a reception room with the supposed social status of the owners. A milestone in this process has been M. Rostovtzeff's attempt to define the owner's economic investment through the frieze observation. Since then, if the link between the frieze and economic implication is less stressed, only a few analyses avoid considering the owners as freedmen, thus in the shadow of Trimalcio. In parallel, part of the Cupids was also subject of investigation in order to try to determine their supposedly precise productive activities or was used as a realistic illustration of production processes as fulling or perfume-making.

This paper aims at reconsidering the frieze in its functional context, in a room mainly designed to accommodate feasts, in order to propose a new reading, without any hypothetical social inference.

A careful analysis of the Cupids' activity, compared with what can be known of the involved production processes, permits to discard any idea of realistic representation. Instead, from this modern 
understanding, it is possible to establish the links between the occupants of the house, the painters' workshop and the guests. The productive scenes, adapted, embedded and intermixed with traditional banquet and Greek culture themes, point towards the definition of a shared technical culture amongst elites.

\section{Bibliography}

Allison 2001 = Allison, P. M., Placing Individuals: Pompeian Epigraphy in Context, Journal of Mediterranean Archaeology 14/1 (2001), 53-74.

Allison 2004a = Allison, P. M., Pompeian Households. An Analysis of the Material Culture, Berkeley 2004 (Cotsen Institute of Archaeology Monograph 42).

Allison 2004b = Allison, P. M., Pompeian Households. An on-Line Companion, http://www. stoa.org/projects/ph/home (accessed February 29, 2016).

Amarger 2009 = Amarger, M.-P., "Le meilleur et le pire serviteur de l'humanité". Fer, forges et forgerons à Pompéi, in: Brun, J.-P. (Ed.), Artisanats antiques d'Italie et de Gaule. Mélanges offerts à Maria Francesca Buonaiuto, Naples 2009 (Archéologie de l'artisanat antique 2), 135-168.

Blanc \& Gury 1986 = Blanc, N. \& Gury, F., s.v. Eros / Amor, Cupido, Lexicon Iconographicum Mythologiae Classicae III/1 (1986), 952-1049.

Blümner 1912 = Blümner, H., Technologie und Terminologie der Gewerbe und Künste bei Griechen und Römern, Leipzig ${ }^{2} 1912$.

Bruneau 1984 = Bruneau, P., Les mosaïstes antiques avaient-ils des cahiers de modèles ?, Revue archéologique (1984), 241-272.

Bruneau 2000 = Bruneau, P., Les mosaïstes antiques avaient-ils des cahiers de modèles ? (suite, probablement sans fin), Ktèma 25 (2000), 191-197. [218]

Brun 2000 = Brun, J.-P., The Production of Perfumes in Antiquity: The Cases of Delos and Paestum, American Journal of Archaeology 104/2 (2000), 277-308.

Brun 2003 = Brun, J.-P., Le vin et l'huile dans la Méditerranée antique: viticulture, oléiculture et procédés de transformation, Paris 2003 (Collection des Hespérides).

Brun 2004 = Brun, J.-P., Archéologie du vin et de l'huile dans l'Empire romain, Paris 2004 (Collection des Hespérides).

Brun \& Monteix 2009 = Brun, J.-P. \& Monteix, N., Les parfumeries en Campanie antique, in: Brun, J.-P. (Ed.), Artisanats antiques d'Italie et de Gaule. Mélanges offerts à Maria Francesca Buonaiuto, Naples 2009 (Archéologie de l'artisanat antique 2), 115-133.
Cameron 1976 = Cameron, A., Circus Factions. Blues and Greens at Rome and Byzantium, Oxford 1976.

Catalano \& Musco 2011 = Catalano, P. \& Musco, S., Preuves anthropologiques de l'emploi d'une main d'œuvre enfantine dans l'entreprise pré-indutrielle de Casa Bertone (Rome I IIII ${ }^{\text {e }}$ siècles), in: Gourevitch, D., Pour une archéologie de la médecine romaine, Paris 2011 (Pathographie 8), 48-51.

Clarke 2003 = Clarke, J. R., Art in the Lives of Ordinary Romans: Visual Representation and Non-elite Viewers in Italy, 100 B.C.-A.D. 315, Berkeley 2003.

De Angelis 2011 = De Angelis, F., Playful Workers. The Cupid Frieze in the Casa Dei Vettii, in:

Poehler, E. et al. (eds.), Pompeii. Art, Industry and Infrastructure, Oxford 2011, 62-73.

Della Corte 1965 = Della Corte, M., Case ed abitanti di Pompei, Napoli ${ }^{3} 1965$.

De Noblet 1981 = de Noblet, J., Culture Technique et Changement de Société, Culture technique 6 (1981), $11-47$.

Dunbabin 2003 = Dunbabin, K. M. D., The Roman Banquet: Images of Conviviality, C ambridge - New York 2003.

Duvauchelle et al. 2012 = Duvauchelle, A. et al., Les lits en bronze d'Avenches: développement des aspects techniques et épigraphiques, Bulletin de l'Association Pro Aventico 54 (2012), 7-118.

Ely $1896=$ Ely, T., The Process of Coining as Seen in a Wall-Painting at Pompeii, Numismatic chronicle 16 (1896), 53-58.

Espérandieu \& Lantier 1911 = Espérandieu, É. \& Lantier, R., Recueil général des bas-reliefs, statues et bustes de la Gaule romaine. Tome quatrième, Lyonnaise. Deuxième partie, Paris 1911 (Collection de documents inédits sur l'histoire de France).

Esposito 2009 = Esposito, D., Le officine pittoriche di IV stile a Pompei dinamiche produttive ed economico-sociali, Roma 2009 (Studi della Soprintendenza archeologica di Pompei 28).

Flohr 2013 = Flohr, M., The World of the Fullo, Oxford 2013 (Oxford studies on the Roman economy).

Fröhlich 1991 = Fröhlich, T., Lararien- und Fassadenbilder in den Vesuvstädten. Untersuchungen zur "volkstümlichen" pompejanischen Malerei, Mainz 1991 (Mitteilungen des Deutschen Archaeologischen Instituts, Roemische Abteilung. Ergänzungsheft 32).

Guillaume-Coirier 1995 = Guillaume-Coirier, G., Images du coronarius dans la littérature et l'art de Rome, Mélanges de l'École française de Rome. Antiquité 107/2 (1995), 1093-1151.

Helbig 1868 = Helbig, W., Wandgemälde der vom Vesuv verschütteten Städte Campaniens, Leipzig 1868. 
Kastenmeier 2007 = Kastenmeier, P., I luoghi del lavoro domestico nella casa pompeiana, Roma 2007 (Studi della Soprintendenza archeologica di Pompei 23). [219]

Mattingly 1990 = Mattingly, D. J., Paintings, Presses and Perfume Production at Pompeii, Oxford Journal of Archaeology 9/1 (1990), 71-90.

Mau 1896 = Mau, A., Scavi di Pompei 1894-1895. Reg. VI, Isola ad E della 11, Mitteilungen des Deutschen Archaeologischen Instituts, Römische Abteilung 11 (1896), 3-97.

Minaud 2006 = Minaud, G., Des doigts pour le dire, Histoire \& mesure 21/1 (2006), 3-34.

Mols 1999 = Mols, S. T. A. M., Wooden Furniture in Herculaneum: Form, Technique and Function, Amsterdam 1999 (Circumvesuviana 2).

Monteix 2010 = Monteix, N., Les lieux de métier. Boutiques et ateliers d'Herculanum, Rome 2010 (Bibliothèque des Écoles françaises d'Athènes et de Rome 344).

Nadeau 2010 = Nadeau, R., Les manières de table dans le monde gréco-romain, Rennes 2010 (Table des hommes).

Pernot 2011 = Pernot, M., Quels métiers les arts des plombiers, bronziers et orfèvres impliquent-ils?, in: Monteix, N. \& Tran, N. (Eds.), Les savoirs professionnels des gens de métier. L'études sur le monde du travail dans les sociétés urbaines de l'empire romain, Naples 2011 (Collection du Centre Jean Bérard 37), 101-118.

Petersen 2006 = Petersen, L. H., The Freedman in Roman Art and Art History, Cambridge - New York 2006.

Picaud 2004 = Picaud, S., Les représentations des jeux de la balle et des osselets dans les terres cuites, céramiques et reliefs, Pallas 65 (2004), 49-55.

Reinach 1892 = Reinach, S., s.v. Ephedrismos, Dictionnaire des antiquités grecques et romaines 2/1 (1892), 636-638.

Roller 2003 = Roller, M., Horizontal Women: Posture and Sex in the Roman convivium, The American Journal of Philology 124/3 (2003), 377-422.

Rossiter \& Haldenby 1989 = Rossiter, J. J. \& Haldenby, E., A Wine-Making Plant in Pompeii Insula II.5, Échos du monde classique = Classical Views 33/2 (1989), 229-239.

Rostovtzeff 1957 = Rostovtzeff, M. I., The Social and Economic History of the Roman Empire, Oxford 21957.

Roux \& Barré 1839 = Roux, H. \& Barré, L., Herculanum et Pompéi. Recueil général des peintures, bronzes, mosaïques, etc. découverts jusqu'à ce jour, et reproduits d'après "Le antichita di Ercolano", il "Museo borbonico", et tous les ouvrages analogues, augmenté de sujets inédits, gravés au trait sur cuivre par H. Roux aîné, et accompagné d'un texte explicatif par M. L. Barré, Paris 1839.

Sampaolo 1994 = Sampaolo, V., VI 15, 1. Casa dei Vettii, in: Pompei. Pitture e mosaici. Vol. V. Regio VI parte seconda, Roma 1994, 468-572.

Sauron 1994 = Sauron, G., Pour une archéologie du regard, in: Quis deum ? L'expression plastique des idéologies politiques et religieuses à Rome à la fin de la République et au début du Principat, Rome 1994 (Bibliothèque des Écoles françaises d'Athènes et de Rome 285), 1-23.

Sogliano 1898 = Sogliano, A., La Casa Dei Vettii in Pompei, Monumenti antichi pubblicati per cura dell'Accademia dei Lincei 8 (1898), 233-388.

Tameanko 1990 = Tameanko, M., Goldsmiths, Mint or Jewellery Factory? A New Interpretation of Pompeian Wall-Painting, Minerva 1/8 (1990), 42-46.

Tran 2013 = Tran, N., Dominus tabernae. Le statut de travail des artisans et des commerçants de l'Occident romain ( $\mathrm{I}^{\mathrm{er}}$ siècle av. J.-C. - $\mathrm{III}^{\mathrm{e}}$ siècle ap. J.-C.), Rome 2013 (Bibliothèque des Écoles françaises d'Athènes et de Rome 360). [220]

Trendelenburg 1874 = Trendelenburg, A., Erotenfries aus Pompeji, Archäologische Zeitung 31 (1874), 44-48.

Weber et al. 2011 = Weber, V. et al. (Eds.), Inscriptiones parietariae Pompeianae. Supplementi. Pars quarta. Fasciculus primum ad titulos pictos spectantem, Berlin 2011 (Corpus inscriptionum Latinarum IV, suppl. 4, 1).

Wyler 2004 = Wyler, S., Dionysos domesticus. Les motifs dionysiaques dans les maisons pompéiennes et romaines ( $\mathrm{II}^{\mathrm{e}} \mathrm{s}$. av. $-\mathrm{I}^{\mathrm{er}}$ s. ap. J.-C.), Mélanges de l'École française de Rome. Antiquité 116/2 (2004), 933-951.

Zanker 1994 = Zanker, P., Nouvelles orientations de la recherche en iconographie. Commanditaires et spectateurs, Revue Archéologique (1994), 281-293.

Zimmer 1982 = Zimmer, G., Römische Berufsdarstellungen, Berlin 1982 (Archäologische Forschungen 12). [221] 